\title{
WÊRELDGEBEURE GEDURENDE DIE JAAR 1954.
}

\section{OORSESE LANDE.}

Die jaar 1954 het begin sonder Stalin, die magtigste diktator van die moderne tyd, en dit was nog onseker hoe die nuwe regime sou optree. Teen die einde van die jaar weet ons nou dat hulle oënskynlik meer toeskietlik is maar in wese nog net so geheimsinnig en nog net so geslepe. Die Petrof-geskiedenis in Australië het weereens laat blyk dat daar oor die hele aarde 'n netwerk van spioene is. Dit is nog maar uiters moeilik om met die Kommuniste te praat, soos op die verskillende konferensies geblyk het. Dat na die mislukking van die Berlynse konferensie in Genève tog iets bereik is en die oorlog in Indo-China tot 'n einde gekom het, moet toegeskryf word aan die energie van Eden en Mendès-France. Daarby moet in die oog gehou word dat die Kommuniste in Indo-China, net soos in Korea, tog bereik het dat weer 'n streep deur 'n land getrek is en dat hulle behou wat hulle verower het.

Die posisie van die Weste het tydelik verswak as gevolg van die verdeeldheid tussen Amerika en Engeland. Churchill het spesiaal na Amerika gegaan on eenheid te probeer verkry, maar by sy terugkeer was die beste wat hy kon sê: "We have not altogether failed". Die beleid van die Britte is tans die van vreedsame koëksistensie met die Kommuniste, terwyl Amerika op geen enkele punt 'n swakheid wil vertoon ter wille van vreedsame saamwoning nie. Amerika glo blykbaar dat die Kommunis net een taal verstaan, naamlik die van krag.

'n Mens kan die houding van Engeland enigsins verstaan as daaraan gedink word dat ' $n$ volgende wêreldoorlog sonder enige twyfel die einde van Brittanje en sy ryk sal beteken. Aan die ander kant is dit ook weer. duidelik dat die Kommuniste elke blyk van swakheid aan die kant van die Westerse moondhede terdeë uitbuit. Sodra die Weste tekens van eensgesindheid toon, kom hulle met versoenende voorstelle.

Die verskrikkinge van die waterstofbom, wat gedurende hierdie jaar in al hul demoniese wreedheid openbaar geword het, sou baie bydra tol die uiterste poginge om ten minste ten opsigte van Europa die Westerse eenheid te bewaar. Ook hier het Eden en Mendès-France die hoofrolle gespeel, nadat Dulles blykbaar toegestem het om die saak aan die Europeane oor te laat.

Hoewel die Europese verdedigingsgemeenskap in duie gestort het, vergoed die Londense verdrag tot 'n groot mate daarvoor. Dit is werklik 
iets om voor dankbaar te wees dat daar weer so 'n goeie verstandhouding tussen Duitsland en Frankryk is, hoewel die Duitse toegewinge in verband met die Saar moontlik weer 'n vuurherd kan word. Dr. Adenauer het homself ' $n$ wyse en vérsiende staatsman betoon. So sal Wes-Duitsland dan weer 'n soewereine staat word. 'n Mens wil hoop dat die HERE aan hierdie energieke volk ook in die toekoms bekwame leiers sal gee, sodat hulle wat die vernaamste bolwerk teen die Kommunisme in Europa is, weer 'n ereposisie in die ry van die kultuurvolke kan inneem. Mag dit ook so wees dat daar Christelike regeerders kom wat sterk kan optree teen ' $n$ moontlike herlewing van die Nasionaal-Sosialistiese heidendom.

\section{Die Verre Ooste.}

Dit is maar goed dat daar in die Weste meer eenheid gevind is, want die Oosterlinge is rusteloos besig om hulself te konsolideer. Wel is daar 'n Oos-Asiatiese verdedigingsorganisasie in die lewe geroep onder leiding van Amerika, maar slegs twee Oosterse state behoort daaraan, naamlik Pakistan en Birma. Die Oosterlinge ken maar net een wagwoord en dit is: die Westerlinge moet uit die Ooste trap! Nehru skyn die sentrale figuur te wees en hy is hard besig om 'n hegte bondgenootskap tussen Indiē en Kommunistiese China te smee. Om 'n indruk te verkry van die mag waaroor die Ooste beskik, moet 'n mens bedink dat Nehru en Chu-en-Lai saam oor 900-miljoen mense regeer!

Die grootste bron van moeilikhede in die Verre Ooste bly Formosa. Mao Tse Tung sal dit nie op die lange duur duld dat hierdie eiland aan die Nasionaliste behoort nie, en aan die ander kant het Eisenhower baie uitdruklik verklaar dat die Kommuniste oor die Amerikaanse vloot na Formosa sal moet gaan. Ondertussen is daar maar gedurig insidente en ' $n$ mens weet nie wanneer die vonk in die kruitvat val nie. Die oorwinning van die Demokrate was vir Eisenhower ongetwyfeld 'n terugslag maar dit sal op die buitelandse beleid seker geen noemenswaardige invloed hê nie. In hierdie opsig verskil Republikeine en Demokrate nie veel nie.

\section{AFRIKA.}

Een van die belangrikste gebeurtenisse vir ons kontinent gedurende die afgelope jaar was die ooreenkoms dat die Britte die Suezkanaal sal ontruim. Churchill het verklaar dat die waterstofbom daarmee te doen het. In 'n toekomstige oorlog kan die Suezkanaal naamlik deur een van hierdie bomme buite werking gestel word, sodat dit nutteloos vir enige 
Westerse nasie is om daar troepe te hou. Dit beteken egter dat die sleutels tot Afrika aan die Ooste oorgegee is. Asië en Afrika sal altyd meer met mekaar kontak soek.

Al hierdie ontwikkelinge het die strategiese betekenis van Suid-Afrika -en veral van ons hawens-oneindig verhoog. As die Suezkanaal onbruikbaar is, word die suidpunt van Afrika die verbindingsweg tussen Oos en Wes. Daarom is dit seker dringend noodsaaklik dat ons in hierdie verband met Amerika tot ' $n$ verstandhouding kom. Dit is in hulle belang net sowel as in die van ons. Brittanje kan ons nie help nie en dit word vir ons altyd gevaarlik om in sy strategie ingesluit te word met uitsluiting van Amerika en ander Westerse volke. Engeland is vandag ons bondgenoot teen die Kommunisme en ons sal goeie vriende moet bly, maar ons lidmaatskap van die Britse Statebond is oorsaak dat ons altyd via Londen moet werk en nie direk kontak met 'n land as Amerika kan soek nie.

Ondertussen is die binneland van Afrika besig om op groot skaal te ontwikkel. 'n Mens moet maar' $n$ boek soos die van Gedat lees om onder die indruk hiervan te kom ("Wat groeit er uit dit Afrika?"). Gedat is baic stellig in sy bewering: „Die heerskappy van die witman in Afrika loop ten einde, of ons dit wil weet of nie". Dit is sover as 'n méns kan sien. Maar daar is Een wat verder sien en in sy Hand berus dic regering en dic toekoms. Dit is ons saak om ons plig te doen, soos dit duidelik in sy Woord omskryf is.

\section{SUID-AFRIKA.}

Die belangrikste gebeurtenisse in ons eie vaderland is ongetwyfeld die herlewing van die republikeinse ideaal en die versterking van die Dietse bande as gevolg van die besock van prins Bernhard.

Waaraan die plotselinge oplewing van die republikeinse propaganda toegreskryf moet word, is vir 'n nie-ingewyde moeilik om te sê. Nog nie te lank gelede nie het ons uit die mond van leiers gehoor dat ons uiters versigtig moet wees met die republiek want Amerika kan teen ons draai as ons van Engeland vervreemd raak en dit kan ons ekonomies noodlottig tref. Onlangs kon ons nou hoor in 'n toespraak van iemand wat met gesag kan praat dat ons die republiek nog in ons leeftyd kan verwag. Selfs dr. Malan, wat in hierdie opsig seker die allerversigtigste was, het in glasheldere taal by die onthulling van die Krugermonument gepraat.

Moontlik het ons dit alles te danke aan die uitslae van die Provinsiale verkiesings. Hieruit het duidelik geblyk dat die dag nie meer ver af is waarop ons die vereiste meerderheid by 'n volkstemming of spesiale 
verkiesing kan verkry nie. Ons Afrikaners is altyd so konsideraat dat die moontlikheid nie uitgesluit was nie dat ons sou bedank het as die republiek ons op 'n goeie dag aangebied is.

Die onthulling van die standbeelde van Kruger en De Wet het ongetwyfeld ook hul stempel nagelaat. Alles bymekaargeneem kan ons sê dat die stryd van nasionalisme gewin is en dat die dae van die imperialisme getel is. Mag ons die hoop uitspreek dat ons nou dadelik begin aan die verstewiging van die Christelike grondslae van ons volk. Anders word ons nasionalisme 'n gevaarlike "kultus".

Die aftrede van dr. Malan val saam met hierdie rekordjaar vir die Afrikaner. Hiermee is ' $n$ tydperk in die geskiedenis van Suid-Afrika afgesluit. Aan dr. Malan moet die eer gegee word dat hy sy beginsels konsekwent uitgeleef het. As 'n mens lees wat Gedat van die Eerste Minister sê, kan jy nie anders nie as om onder die indruk te kom dat hy 'n kragtige persoonlikheid was, ook al sou daar verskille bestaan. Ondersteuners van die Potchefstroomse Universiteit en van Koers sal dr. Malan altyd dankbaar bly dat hy eers aan die Universiteit sy „van" (vir C.H.o.) teruggegee het en later die tyd van sy Regering afgestaan het om ons wet deur te loods-sonder 'n gewetensklousule! Dat hy vroeër nie geneë was om die gewetensklousule te skrap nie, was ook weer heeltemal in oorecnstemming met die beginsels waarvolgens hy in Utrecht opgelei is, dat nl. godsdiens en wetenskap lyne is wat mekaar nie kruis nie. Gedurende dic twintigste eeu het die gedagte van 'n neutrale wetenskap veld verloor en diegene wat in ons land nog altyd vir 'n Christelike wetenskap geywer het sal dr. Malan dankbaar bly dat hy later in hierdie opsig so toeskietlik was Veral in sy later lewe het hy sy godsdienstige oortuiginge in sy toesprake onbeskroomd uitgespreek. Hy kan met voldoening op sy loopbaan terugkyk.

Die keuse van die nuwe eerste minister was eintlik 'n vanselfsprekende saak. Adv. Strydom het homself gekies. Dit is begryplik dat daar ook nog aan innr. Havenga gedink is-iemand met 'n lang en eerbare politieke loopbaan wat soet en suur saam met sy volk deurgemaak en meegehelp hel aan die eenwording van die Afrikanerdom. Dat hy as teleurgestelde die politieke arena moes verlaat, is 'n stukkie tragiek, maar hy kan hom getroos voel dat dit nie om sy persoon gaan nie. Dit is die „magtige dreuning" van Jong Suid-Afrika wat onkeerbaar vorentoe beur en in adv. Strydom die eksponent vind van hul hoogste aspirasies. Dit tyd van die politieke filosofie van mnr. Havenga is verby. Onder sy leiding sou ons 'n hele aantal jare weer die pas gemarkeer het wat ons eindbestemming betref. 
In adv. Strydom sien ons weer duidelik waarheen ons volk wil. Jarelank was hy die eensame verkondiger van die ideologie wat tans geseëvier het. Ten slotte gaan dit om die konsekwente uitlewing van beginsels. In sy radiorede het die nuwe Eerste Minister dadelik begin met sy vertroue op God. Hy het die regte snare aangeroer. Die samestelling van sy kabinet en die herverdeling van portefeuljes sal weining ruimte vir kritiek laat. 'n Spesiale woord van gelukwensing aan die oud-Potchefstromer en oudP.U.-kaner mnr. Jan de Klerk. Hy het vir die nasionale saak reeds onskatbare dienste gelewer en ons verwag van hom nog veel in die tockoms. Adv. Strydom het gevra dat sy volk hom en sy regering in die gebede sal gedenk. Hy kan daarvan seker wees dat dit sal gebeur.

Miskien moet aan die einde nog net beskeidenlik vermeld word dat aan die begin van die jaar 'n blad met 'n heeltemal eie stempel die lig gesien het. Ons bedoel Woord en Daad-nog maar'n klein babetjie, maar een wat so stadigaan 'n eie geluid laat hoor as 'n jonger broertjie van Koers en wat hom veral ten doel stel om die Christelik-Nasionale beginsels in ons volkslewe te verbrei. 